\title{
Frequency of Toxoplasma gondii antibodies in bovines in the state of Pernambuco, Brazil
}

\author{
Frequência de anticorpos anti-Toxoplasma gondii em bovinos do estado de Pernambuco, Brasil \\ Neurisvan Ramos Guerra ${ }^{1 *}$; Bruno Henrique Leal e Silva Alves²; Márcia Paula Oliveira Farias³ \\ Rinaldo Aparecido Mota²; Leucio Câmara Alves ${ }^{1}$
}

\author{
${ }^{1}$ Laboratório de Doenças Parasitárias dos Animais Domésticos, Programa de Pós-graduação em Biociência Animal, \\ Universidade Federal Rural de Pernambuco - UFRPE, Recife, PE, Brasil \\ ${ }^{2}$ Laboratório de Bacterioses, Programa de Pós-graduaçăo em Biociência Animal, Universidade Federal Rural de \\ Pernambuco - UFRPE, Recife, PE, Brasil \\ ${ }^{3}$ Universidade Federal Rural do Piauí - UFPI, Campus Universitário Profa. Cinobelina Elvas, Bom Jesus, PI, Brasil
}

Received May 5, 2014

Accepted June 11, 2014

\begin{abstract}
Toxoplasmosis is a parasitic disease caused by Toxoplasma gondii that affects homeothermic animals, including humans. Felines are considered the definitive host of this parasite, while other animals act as intermediate hosts. The purpose of this study was to assess the frequency of anti-T. gondii $\operatorname{IgG}$ antibodies in bovines in the state of Pernambuco, Brazil. Serum samples $(n=427)$ from animals in 13 municipalities of the coastal forest/plantation region of the state were analyzed using the immunofluorescent antibody test (IFAT). The overall results revealed a prevalence rate of $16.63 \%$ (27/427). High percentages of positivity were found among animals aged 25 to 36 months (28.57\%; 30/42) and in males $(22.22 \% ; 2 / 9)$. The present findings suggest that bovine toxoplasmosis is endemic in the area under study.

Keywords: toxoplasmosis, parasitic disease, infection, zoonosis, diagnosis,; immunofluorescent antibody test.

\section{Resumo}

Toxoplasmose é uma doença parasitária que infecta todos os animais homeotérmicos, incluindo o homem. Na epidemiologia da infecção, os felinos são os hospedeiros definitivos, e outros animais são os hospedeiros intermediários do Toxoplasma gondii. O objetivo deste trabalho foi determinar a frequência de anticorpos IgG anti-Toxoplasma gondii em bovinos do Estado de Pernambuco. Para tanto, foram coletadas 427 amostras de soro sanguíneo de bovinos provenientes de 13 municípios localizados na Zona da Mata do Estado de Pernambuco. Tais amostras foram analisadas pela técnica de Imunofluorescência Indireta para pesquisa de anticorpos anti-Toxoplasma gondii. A frequência observada foi de $16,63 \%$ (27/427). Anticorpos anti-Toxoplasma gondii foram mais frequentes $(28,57 \%)$ em animais com idade entre 25-36 meses de idade. Considerando-se por sexo, observou-se uma maior positividade entre os machos que apresentaram 22,22\% (2/9). Os resultados demonstram que a toxoplasmose é endêmica nessa regiấo.
\end{abstract}

Palavras-chave: toxoplasmose, doença parasitária, infecção, zoonose, diagnóstico, imunofluorescência indireta.

\section{Introduction}

Toxoplasmosis is a parasitic disease caused by the protozoan Toxoplasma gondii, which has a cosmopolitan distribution and can infect different species of animals, including humans (TENTER et al., 2000). Wild and domestic felines are considered the definitive hosts. Enteroepithelial multiplication of the protozoan occurs in these species, resulting in the production of oocysts and elimination through the feces (DUBEY et al., 1977).

\footnotetext{
${ }^{*}$ Corresponding author: Neurisvan Ramos Guerra

Laboratório de Doenças Parasitárias dos Animais Domésticos, Departamento de Medicina Veterinária, Universidade Federal Rural de Pernambuco - UFRPE, Rua Dom Manoel de Medeiros, s/n, Dois Irmãos, CEP 52171-900, Recife, PE, Brasil

e-mail: neurisvan.guerra@hotmail.com
}

Among livestock, infection by T. gondii has been reported in several species, with goats, sheep and pigs showing greater susceptibility than cattle and horses (MILLAR et al., 2008). Infection can have a negative effect on reproduction in these animals, which may lead to economic losses. In bovines, T. gondii cysts have been found in the retina and diaphragm, indicating the participation of this species in the transmission of the parasite (AMATO NETO et al., 1995).

Considering the importance of toxoplasmosis to both public and animal health, the purpose of this study was to determine the seroprevalence of anti-T. gondii IgG antibodies in bovines in different municipalities in the coastal forest/plantation region of the state of Pernambuco, Brazil. 


\section{Materials and Methods}

\section{Study area}

The coastal forest/plantation region $\left(34^{\circ} 80^{\prime} \mathrm{E} 30^{\circ} 20^{\prime} \mathrm{W}\right)$ comprises 43 municipalities and covers an area of $8738 \mathrm{~km}^{2}$ in the state of Pernambuco, corresponding to $8.9 \%$ of the state's total territory. Animals from 13 municipalities of this region were analyzed in the present study.

\section{Samples}

Serum samples $(\mathrm{n}=427$ ) were kindly provided by the National Livestock Laboratory of Pernambuco. The samples came from crossbred animals in different municipalities in the coastal forest/plantation region of the state and were analyzed using the immunofluorescent antibody test (IFAT), following the method described by Camargo (1964). A titer of 1:64 was used as cutoff (DAGUER et al., 2004).

\section{Statistical analysis}

The data were analyzed using the chi-square test or Fisher's exact test with the aid of the BioEstat program (version 5.0; Mamirauál CNPq, Belém, PA, Brazil) (AYRES et al., 2007).

\section{Results and Discussion}

Among the 427 samples tested, 16.63\% (71/427) scored positive for anti- $T$. gondii $\operatorname{IgG}$ antibodies. This prevalence rate is higher than rates previously reported in the states of Bahia, São Paulo, Minas Gerais and Mato Grosso do Sul, which ranged from 3.2 to $12 \%$ (ARAÚJO et al., 1998; GONDIM et al., 1999), but lower than rates reported by Marana et al. (1994), Marana et al. (1995), Costa (2001), Daguer et al. (2004) and Ogawa et al. (2005), who detected anti-T. gondii antibodies in cattle in the states of Amazonas, São Paulo, Paraná and Rio Grande do Sul (prevalence rate: 25.8 to $49.9 \%$ ). The present results (Table 1) are similar to those reported by Albuquerque et al. (2005) for the state of Rio de Janeiro, who detected $14.77 \%$ positivity (87/589) among the animals using the IFAT.

In a previous study carried out in the Agreste (a region of transition between the coastal and semi-arid regions of the interior of the state) and the coastal forest/plantation region of Pernambuco, Silva et al. (2003) detected $51.96 \%$ positivity using IFAT, with a higher prevalence rate found in the coastal forest/plantation region. The climatic conditions of this region favor the maintenance of viable oocysts in the environment, which are an important source of transmission to herbivores (SILVA et al., 2003).

From the public health standpoint, the epidemiology of toxoplasmosis in bovines is very important. Cattle can be infected through the ingestion of pasture containing $T$. gondii oocysts, which is frequently observed in extensive farming systems (MARANA et al., 1994). Moreover, congenital transmission occurs when females acquire the infection and transmit it to the fetus (MILLAR et al., 2008). However, it should be stressed that although bovines may be infected, they rarely develop clinical signs of the disease (DUBEY; THULLIEZ, 1993).

Despite the fact that bovines seem to be more resistant to infection than other animals (DUBEY, 1994), the parasites may remain viable in their tissues until slaughtering age (DUBEY, 1983), as cysts have been found in the retina and diaphragm of cattle (AMATO NETO et al., 1995). In this context, people who handle beef without proper hygiene may play an important role in maintaining T. gondii (DAGUER et al., 2004).

In Brazil, there has been an increase in the consumption of raw or undercooked beef, especially in areas with no federal inspection service. It has been demonstrated that $T$. gondii cysts remain viable for 4 minutes when subjected to $60{ }^{\circ} \mathrm{C}$ and up to 10 minutes when subjected to $50{ }^{\circ} \mathrm{C}$. These data demonstrate that some cysts may survive the cooking process, especially when cooking does not occur evenly, as in microwave ovens (LUNDÉN; UGGLA, 1992). Similarly, cysts can remain infective in carcasses refrigerated from 1 to $4{ }^{\circ} \mathrm{C}$ for more than three weeks and carcasses kept at -8 to $-1{ }^{\circ} \mathrm{C}$ for more than one week (KOTULA et al., 1991).

Contaminated milk and dairy products containing viable tachyzoites constitute another important source of infection for humans (HIRAMOTO et al., 2001). It is possible that some risk factors, such as the feline population, exposure to domestic cats and water contamination, may have contributed to the number of positive animals reported herein (ALBUQUERQUE et al., 2011).

When analyzing the data according to age (Table 2), higher positivity was found among animals aged 25 to 36 months of age,

Table 1. Absolute (AF) and relative frequency (RF) of anti-T.gondii IgG antibodies in bovines from the coastal forest/plantation region of Pernambuco.

\begin{tabular}{lcccc}
\hline \multirow{2}{*}{ Municipality } & \multicolumn{2}{c}{ Positive } & \multicolumn{2}{c}{ Negative } \\
\cline { 2 - 5 } & AF & RF (\%) & AF & RF(\%) \\
\hline Água Preta & 6 & 24.00 & 19 & $76.00 \%$ \\
Amaraji & 2 & 13.33 & 13 & 86.67 \\
Barreiros & 0 & 0 & 16 & 100 \\
Chã de Alegria & 5 & 45.45 & 6 & 54.55 \\
Escada & 0 & 0 & 12 & 100 \\
Glória do Goitá & 6 & 12.77 & 41 & 87.23 \\
Macaparana & 0 & 0 & 52 & 100 \\
Maraial & 10 & 40.00 & 15 & 60.00 \\
Palmares & 2 & 11.11 & 16 & 88.89 \\
Pombos & 9 & 13.24 & 59 & 86.76 \\
Quipapá & 3 & 15.00 & 17 & 85.00 \\
São Lourenço da Mata & 10 & $40.00 \%$ & 15 & 60.00 \\
Vitória de Santo Antão & 18 & 19.35 & 75 & 80.65 \\
Total & 71 & 16.63 & 356 & 83.37 \\
\hline
\end{tabular}

Table 2. Absolute (AF) and relative frequency (RF) of anti-T. gondit IgG antibodies in bovines from the coastal forest/plantation region of Pernambuco, as a function of age.

\begin{tabular}{ccccc}
\hline \multirow{2}{*}{$\begin{array}{c}\text { Age } \\
\text { (months) }\end{array}$} & \multicolumn{2}{c}{ Positive } & \multicolumn{2}{c}{ Negative } \\
\cline { 2 - 5 } & AF & RF (\%) & AF & RF (\%) \\
\hline $0-24$ & $3 / 18$ & 16.67 & $15 / 18$ & 83.33 \\
$25-36$ & $12 / 42$ & 28.57 & $30 / 42$ & 71.43 \\
$\geq 36$ & $56 / 367$ & 15.26 & $311 / 367$ & 84.74 \\
Total & $71 / 427$ & 16.63 & $356 / 427$ & 82.67 \\
\hline
\end{tabular}


Table 3. Absolute (AF) and relative frequency (RF) of anti- $T$. gondii IgG antibodies in bovines from the coastal forest/plantation region of Pernambuco, as a function of sex.

\begin{tabular}{ccccc}
\hline \multirow{2}{*}{ Gender } & \multicolumn{2}{c}{ Positive } & \multicolumn{2}{c}{ Negative } \\
\cline { 2 - 5 } & Positive/Total & $\%$ & Positive/Total & $\%$ \\
\hline Female & $69 / 418$ & 16.51 & $349 / 418$ & 83.49 \\
Male & $2 / 9$ & 22.22 & $7 / 9$ & 77.78 \\
Total & $71 / 427$ & 16.63 & $418 / 427$ & 83.37 \\
\hline
\end{tabular}

but this association was not statistically significant $(\mathrm{p}=0.089)$. This finding is in agreement with data reported by Arias et al. (1994), but differs from data reported by Moura et al. (2010), who detected a higher rate of infection in adults.

Regarding the sex of the animals (Table 3), males exhibited a higher rate of positivity (22.22\%). However, the difference between the population size of males and females may have interfered with this result, as previously observed by Moura et al. (2010). Moreover, this association was not statistically significant (Fisher's exact test; $\mathrm{p}=0.648)$.

All the animal samples from the municipalities of Escada, Barreiros and Macaparana scored negative, suggesting that, at that time, the herd was free from $T$. gondii infection.

The frequency of animals testing positive indicates that the coastal forest/plantation region in the state of Pernambuco, Brazil, is an endemic area for $T$. gondii in bovines.

\section{References}

Albuquerque GR, Munhoz AD, Flausino W, Silva RT, Almeida CRR, Medeiros SM, et al. Prevalência de anticorpos anti-Toxoplasma gondii em bovinos leiteiros do Vale do Paraíba Sul Fluminense, Estado do Rio de Janeiro. Rev Bras Parasitol Vet 2005; 14(3): 125-128. PMid:16229757.

Albuquerque GR, Munhoz AD, Teixeira M, Flausino W, Medeiros SM, Lopes CW. Risk factors associated with Toxoplasma gondii infection in dairy cattle, State of Rio de Janeiro. Pesq Vet Bras 2011; 31(4): 287-290. http://dx.doi.org/10.1590/S0100-736X2011000400003

Amato Neto V, Medeiros EAS, Levi GC, Duarte MISD. Toxoplasmose. 4th. ed. São Paulo: Sarvier; 1995. 154 p.

Araújo FR, Carvalho CME, Balbuena CB. Levantamento sorológico para Toxoplasma gondii em bovinos de corte do estado do Mato Grosso do Sul, Brasil. Rev Bras Med Vet 1998; 20(5): 201-203.

Arias LM, Reyes L, Chinchilla M, Linder E. Seroepidemiology of Toxoplasma gondii (Apicomplexa) in meat producing animals in Costa Rica. Rev Biol Trop 1994; 42(1-2):15-20. PMid:7480936.

Ayres M, Ayres M Jr, Ayres DL, Santos AAS. BioEstat 5.0: aplicaçóes estatísticas nas áreas das Ciências Biomédicas. 5. ed. Belém: Sociedade Civil Mamirauá; 2007. 324 p.

Camargo ME. Improved technique of indirect immunofluorescence for serological diagnosis of toxoplasmosis. Rev Inst Med Trop S Paulo. 1964; 3(6): 117-118.

Costa GHN, Cabral DD, Varandas NP, Sobral EA, Borges FA, Castagnolli KC. Freqüência de anticorpos anti-Neospora caninum e anti-Toxoplasma gondii em soros de bovinos pertencentes aos estados de São Paulo e de Minas Gerais. Semin. Cienc. Agrar 2001; 22(1): 61-66.

Daguer H, Vicente RT, Costa T, Virmond MP, Hamann W, Amendoeira MRR. Soroprevalência de anticorpos anti- Toxoplasma gondii em bovinos e funcionários de matadouros da microrregião de Pato Branco, Paraná, Brasil. Ciênc Rural 2004; 34(4): 1133-1137. http://dx.doi.org/10.1590/ S0103-84782004000400026

Dubey JP, Hoover EA, Walls KW. Effect of age and sex the acquisition of immunity to toxoplasmosis in cats. J Protozool 1977; 24(1): 184-186. PMid:864622. http://dx.doi.org/10.1111/j.1550-7408.1977.tb05302.x

Dubey JP, Thulliez P. Persistence of tissue cysts in edible tissues of cattle fed Toxoplasma gondii oocysts. Am J Vet Res 1993; 54(2): 270-273. PMid:8430937.

Dubey JP. Distribuition of cysts and tachyzoites in calves and pregnant cows inoculated with Toxoplasma gondii oocysts. Vet Parasitol 1983; 13(3): 199-201. http://dx.doi.org/10.1016/0304-4017(83)90057-2

Dubey JP. Toxoplasmosis. J Am Vet Med Assoc 1994; 205(11): 15931598. PMid:7730132.

Gondim LFP, Barbosa HV, Ribeiro Filho CHA, Saeki H. Serological survey of antibodies to Toxoplasma gondii in goats, sheep, cattle and water buffaloes in Bahia State. Brasil. Vet Parasitol 1999; 82(2): 273-276. http://dx.doi.org/10.1016/S0304-4017(99)00033-3

Hiramoto RM, Mayrbaurl-Borges M, Galisteo AJ Jr, Meireles LR, Macre MS, Andrade HF Jr. Infectivity of cysts of the ME- 49 Toxoplasma gondii strain in bovine milk and homemade cheese. Rev Saúde Pública 2001; 35(2): 113-118. PMid:11359195. http://dx.doi.org/10.1590/S003489102001000200002

Kotula AW, Dubey P, Sharar AK, Andrews CD, Shen SK, Lindsay DS. Effect of freezing on the infectivity of Toxoplasma gondii tissue cysts in pork. J Food Protec 1991; 54(9): 687-690.

Lundén A, Uggla A. Infectivity of Toxoplasma gondii in mutton following curing, smoking, freezing or microwave cooking. Int J Food Microbiol 1992; 15(3-4): 357-363. http://dx.doi.org/10.1016/01681605(92)90069-F

Marana ERM, Navarro I, Vidotto O, Freire RL, Lott R. Ocorrência de anticorpos anti-Toxoplasma gondii em bovinos de corte, abatidos em matadouros do Norte do Paraná - Brasil. Semin. Cienc. Agrar 1994; 15(1): 38-40.

Marana ERM, Venturini ACH, Freire RL, Vidotto O, Navarro IT. Ocorrência de anticorpos anti-Toxoplasma gondii em rebanhos de bovinos de leite do norte do Paraná - Brasil. Semin. Cienc. Agrar 1995; 16(1): 40-42.

Millar PR, Sobreiro LG, Bonna ICF, Amendoreira MRR. A importância dos animais de produção na infecção por Toxoplasma gondii no Brasil. Semin. Cienc. Agrar 2008; 29(3): 693-706.

Moura AB, Osaki SC, Zulpo DL, Garcia JL, Teixeira EB. Detecção de anticorpos contra Toxoplasma gondii em bovinos de corte abatidos em Guarapuava, PR, Brasil. Arch Vet Sci 2010; 15(2): 94-99.

Ogawa L, Freire RL, Vidotto O, Gondim LFP, Navarro IT. Ocorrência de anticorpos contra Neospora caninum e Toxoplasma gondii em bovinos leiteiros da regiáo norte do Estado do Paraná. Arq Bras Med Vet Zootec 2005; 57(3): 312-316. http://dx.doi.org/10.1590/S010209352005000300006

Silva AV, Cunha ELP, Meireles LR, Gottschalk S, Mota RA, Langoni H. Toxoplasmose em ovinos e caprinos: estudo soroepidemiológico em duas regiōes do Estado de Pernambuco, Brasil. Ciênc Rural 2003; 33(1): 115-119. http://dx.doi.org/10.1590/S0103-84782003000100018

Tenter AM, Heckeroth AR, Weiss LM. Toxoplasma gondii: from animals to humans. Int J Parasitol 2000; 30(12-13): 1217-1258. http://dx.doi. org/10.1016/S0020-7519(00)00124-7 